\title{
Properties of Plywood Produced with Urea- Formaldehyde Adhesive Modified with Nanocellulose and Microcellulose
}

\section{Svojstva furnirskih ploča proizvedenih s urea- formaldehidnim adhezivom modificiranim nanocelulozom i mikrocelulozom}

\author{
Original scientific paper • Izvorni znanstveni rad \\ Received-prispjelo: 18. 3. 2019. \\ Accepted-prihvaćeno: 20. 11. 2019. \\ UDK: $630 * 824.328 ; 630 * 832.282$ \\ https://doi.org/10.5552/drvind.2020.1919
}

\author{
(C) 2020 by the author(s). \\ Licensee Faculty of Forestry, University of Zagreb. \\ This article is an open access article distributed \\ under the terms and conditions of the \\ Creative Commons Attribution (CC BY 4.0) license.
}

\begin{abstract}
Urea-formaldehyde adhesives are widely used in the wood-based materials industry. The study investigates the possibility of using cellulosic particles as a filler that modifies the properties of the resin and consequently improves the properties of plywood. Moreover, the study also examines the differences between microcellulose and nanocellulose used as a filler for UF adhesive. Based on the investigations, it was found that the addition of MFC and NCC significantly affected the curing process and rheological behaviour of adhesive mixtures. Modification led to increase of viscosity and extension of a gel time caused by lowering solid content of the resin. The experimental and reference plywood were tested in terms of bonding quality and mechanical properties such as modulus of elasticity and modulus of rigidity in accordance with applicable standards. The results of the tests confirmed that both the amount and the type of modifier added to the resin had a significant effect on the properties of plywood. The bonding quality and the above mentioned mechanical properties improved in all variants of modification; however the most effective was the addition of NCC in the amount of $10 \% / 100 \mathrm{~g}$ of solid resin. The slight decrease of formaldehyde emission was only observed for $5 \%$ cellulosic particles added to $100 \mathrm{~g}$ of solid UF.
\end{abstract}

Keywords: nanocellulose; microcellulose; urea-formaldehyde resin; plywood; modification

\footnotetext{
SAŽETAK • Urea-formaldehidni (UF) adhezivi imaju široku primjenu u industriji materijala na bazi drva. U radu je opisano istraživanje mogućnosti upotrebe celuloznih čestica kao punila koje mijenja svojstva smole $i$ posljedično poboljšava svojstva furnirske ploče. Nadalje, u istraživanju su ispitane razlike između mikroceluloze (MFC) i nanoceluloze (NCC) koje su upotrijebljene kao punilo za adheziv na bazi UF adheziva. Na temelju ispitivanja utvrđeno je da MFC i NCC dodatci znatno utječu na postupak stvrdnjavanja i reološko ponašanje adhezivnih smjesa. Modifikacija je rezultirala povećanjem viskoznosti i produljenjem vremena geliranja uzrokovanoga smanjenjem sadržaja čvrste smole. Ispitani su kvaliteta vezanja i mehanička svojstva eksperimentalne i referentne furnirske ploče poput modula elastičnosti i modula krutosti, sukladno odgovarajućim normama. Rezultati ispiti-

Authors are research assistant, professor and professor at Department of Wood Based Materials, Faculty of Wood Technology, Poznań University of Life Sciences, Poznań, Poland.

${ }^{2}$ Author is professor at Department of Chemistry, Faculty of Wood Technology, Poznań University of Life Sciences, Poznań, Poland.
} 
vanja potvrdili su da i količina i vrsta modifikatora dodanoga u smolu imaju znatan utjecaj na svojstva furnirske ploče. Kvaliteta vezanja i spomenuta mehanička svojstva poboljšana su pri svim varijantama modifikacija, no najučinkovitije je bilo dodavanje NCC-a u količini od $10 \%$ na $100 \mathrm{~g}$ čvrste smole. Blago smanjenje emisije formaldehida uočeno je samo za $5 \%$ celuloznih čestica dodanih u $100 \mathrm{~g}$ čvrstog UF adheziva.

Ključne riječi: nanoceluloza, mikroceluloza, urea-formaldehidna smola, furnirska ploča, modifikacija

\section{INTRODUCTION 1. UVOD}

Thanks to its unique properties, plywood is one of the most important products of the wood-based materials global industry. It is a valuable wood-based panel, widely used as a finishing and constructional material with very advantageous mechanical properties resulting from its layered structure (Bekhta et al., 2016). The adhesion properties of veneers may seem similar to solid wood, and however, there are many operations during the plywood panel manufacturing processes, e.g. shearing and drying, that can affect the chemical and physical properties of the veneer surface (Munoz and Moya 2018). The commonly used adhesives for plywood production are urea-formaldehyde (UF) resins. The European production of aminoplastic adhesives was estimated to be $5.5 \times 10^{6}$ metric tons (Zhang et al., 2011; Mahrdt et al., 2016). The widespread use of these resins is due to their high reactivity, low cost, ease of processing and lack of colour (Dunky and Niemz, 2002; Dukarska, 2011). However, ureaformaldehyde adhesives are severely disadvantaged by the formaldehyde emissions from the manufactured wood-based panels (Gao et al., 2018). The strength parameters of UF adhesive bonds is limited - it results from the stress concentrations along the bond line of wood adhesive joint and leads to deterioration of the mechanical properties (Veigel et al., 2012). In the past, many studies have been carried out to improve the properties of resins, e.g. by chemical modifications (Dziurka and Mirski, 2010; Dziurka et al., 2014) or addition of various kinds of fillers. The fillers for resins used in plywood industry are non-volatile, insoluble materials that can affect the reactivity and the viscosity of the plywood (Dukarska and Czarnecki, 2016). A number of studies considered fillers such as glass fibre, talc, $\mathrm{TiO}_{2}$ and many more (Lęcka et al., 2013), but due to their relatively large particles, it is hard to obtain a good level of homogenization. Without proper dispersion of the filler in the adhesive mixture, it is difficult to spread it properly on the surface of the veneer. In recent years, nanotechnology has been associated with very high expectations and the developments in this field have led to improvements of the properties of resins (Ahmad et al., 2010; May et al., 2010; Veigel et al., 2011; Ates et al., 2013; Bardak et al., 2017). Nanoclayreinforced urea-formaldehyde adhesive reveals increased water resistance, internal bonding of panels and improved thermal stability (Lei et al., 2008; Zahedsheijani et al., 2012). One of the most commonly used filler is nano-silicon dioxide. Addition of the silica can increase reactivity of the resin and leads to the possibility of reducing the amount of resin applied on the surface of veneers (Leonovich et al., 2002; Lin et al., 2006; Roumeli et al., 2012; Dukarska and Czarnecki, 2016). Recently, it has been revealed that the addition of micro and nano fibres of cellulose may have advantageous effects on the properties of resin. Due to form and size, cellulose particles can be divided into three groups: MFC (microfibrillated cellulose), cellulose nanocrystals sometimes called whiskers (NCC) and nanofibrillated cellulose (NFC) (Hubee et al., 2008; Pawlak and Boruszewski, 2018). Environmental friendliness has been a motivation for the use of cellulosic fillers (Ioelovich 2008). Resources of this natural polymer are estimated at $1.5 \times 10^{12}$ tons per year (Klemm et al., 2005). Pawlak and Boruszewski (2018) used MFC for reinforcing UF resin during the lowdensity particleboards production. Studies revealed that the addition of microcellulose had a positive effect on water resistance, modulus of rupture and modulus of elasticity. Moreover, the addition of MFC to UF resin made it more viscous (Mahrdt et al., 2016). The addition of nanocellulose also improved the mechanical performance of particleboards and OSB boards (Veigel et al., 2012). Also in case of low-density particleboards, standard particleboards and OSB boards, improvement in adhesive performance can reduce the amount of required resin and lead to significant cost reduction. Results of formaldehyde emission are not fully conclusive. Ayrilmis et al. (2016) revealed that MFC did not work for decreasing formaldehyde emission, and on the other hand Zhang et al. (2011) achieved a significant decrease of $\mathrm{CH}_{2} \mathrm{O}$ emission because of the addition of NCC to UF resin. Thus, the aim of this work was to investigate the effect of the addition of MFC and NCC to urea-formaldehyde resin on the properties of manufactured plywood such as its mechanical performance and formaldehyde emission.

\section{MATERIALS AND METHODS} 2. MATERIJALI I METODE

The adhesive used for research purposes was a commercially available urea-formaldehyde resin (Silekol, Kędzierzyn-Koźle, Poland) with the following characteristics: solid resin content $69 \%$, viscosity 610 mPas, gel time at $100{ }^{\circ} \mathrm{C}, 69 \mathrm{~s}, \mathrm{pH} 8.09$ and density $1.282 \mathrm{~g} / \mathrm{cm}^{3}$. Two types of fillers were used: microfibrillated cellulose with a trade name ARBOCEL (Rettenmaier $\mathrm{GmbH}$, Poland) with average particle sizes of $6 \mu \mathrm{m}-12 \mu \mathrm{m}$ and cellulose nanocrystals with a trade name NG01NC0101-1000 (Nanografi Nanotechnology Co. Ltd., Turkey) with average particle sizes, 10-20 nm wide and 300-900 nm long. Ammonium nitrate $(20 \mathrm{wt} \%)$ was added as a hardener following the 
Table 1 Variants of composition of adhesive mixtures

Tablica 1. Varijante sastava smjesa adheziva

\begin{tabular}{|c|c|c|c|c|c|c|}
\hline \multirow[t]{2}{*}{$\begin{array}{c}\text { Variant } \\
\text { Varijanta }\end{array}$} & \multirow[t]{2}{*}{$\begin{array}{l}\text { Solid UF resin } \\
\text { content, } \mathbf{g} \\
\text { Sadržaj čvrste } \\
\text { UF smole, } \mathrm{g}\end{array}$} & \multicolumn{2}{|c|}{$\begin{array}{c}\text { Amount of filler suspension, } \\
\text { g/100 g d. m. of resin } \\
\text { Količina suspenzije punila, g/100 g } \\
\text { suhe tvari smole }\end{array}$} & \multirow{2}{*}{$\begin{array}{l}\text { Rye flour, } \mathbf{g} / \mathbf{1 0 0} \\
\text { g d. m. of resin } \\
\text { Raženo brašno, } \\
\text { g/100 g suhe tvari } \\
\text { smole }\end{array}$} & \multirow{2}{*}{$\begin{array}{c}\mathbf{H}_{2} \mathbf{O}, \mathbf{g} / \mathbf{1 0 0} \mathbf{g ~ d} . \\
\text { m. of resin } \\
\text { Voda, } \\
\mathrm{g} / 100 \mathrm{~g} \text { suhe } \\
\text { tvari smole }\end{array}$} & \multirow{2}{*}{$\begin{array}{l}\text { Hardener, } \mathbf{g} / \mathbf{1 0 0} \mathbf{g} \\
\text { d. } \mathbf{m} . \text { of resin } \\
\text { Otvrđivač, } \\
\mathrm{g} / 100 \mathrm{~g} \text { suhe tvari } \\
\text { smole }\end{array}$} \\
\hline & & MFC & $\mathrm{NCC}$ & & & \\
\hline 0 & 100 & 0 & 0 & 15 & 15 & 2 \\
\hline M5 & 100 & 5 & 0 & 2 & 0 & 2 \\
\hline M10 & 100 & 10 & 0 & 4 & 0 & 2 \\
\hline M20 & 100 & 20 & 0 & 8 & 0 & 2 \\
\hline N5 & 100 & 0 & 5 & 2 & 0 & 2 \\
\hline N10 & 100 & 0 & 10 & 4 & 0 & 2 \\
\hline $\mathrm{N} 20$ & 100 & 0 & 20 & 8 & 0 & 2 \\
\hline
\end{tabular}

resin supplier recommendation. A number of tests were performed to determine the optimum amount of fillers. Due to the necessity of processing cellulosic particles in wet states, $10 \%$ aqueous suspension was mixed with a magnetic stirrer (700 rpm, $10 \mathrm{~min}$ ). Adhesive mixtures with an amount of MFC and NCC suspension, depending on the variant (Table 1), were prepared. The adhesive filled with cellulosic suspension was mixed with CAT-500 homogenizer at $1000 \mathrm{rpm}$ for 2 minutes to achieve the high level of particles dispersion. In order to explain the effect of the modifier on the chemical structure of the cured UF resin, IR spectroscopy was used. Adhesive mixture in a form of powder was mixed with $\mathrm{KBr}$ (potassium bromide) at a $1 / 200 \mathrm{mg}$ ratio. Spectra were registered using a Nicolet iS5 spectrophotometer (Thermo Fisher Scientific) with Fourier transform at a range of $500-4000 \mathrm{~cm}^{-1}$ at a resolution of $4 \mathrm{~cm}^{-1}$, registering 16 scans. In order to assess the suitability of the reinforced adhesive mixture for plywood production, the following tests were carried out: viscosity and its changes for 8 hours with a Brookfield DV-II + Pro viscometer, gel time at $100{ }^{\circ} \mathrm{C}$ in accordance with Polish standard PN-C-89352-3, pH and solid content according to EN 1245:2011 and EN 827:2005, respectively.

Experimental three-layer plywood panels were manufactured from birch veneers with an average thickness of $1.5 \mathrm{~mm}$ and moisture content of $6 \%$. Veneers were glued with adhesive mixture in the amount of $170 \mathrm{~g} / \mathrm{m}^{2}$. Plywood was manufactured with the following pressing parameters: unit pressure $1.4 \mathrm{MPa}$, temperature $120^{\circ} \mathrm{C}$, time $4 \mathrm{~min}$. Bonding quality $\left(\mathrm{f}_{\mathrm{v}}\right)$ was assessed by shear test in accordance with EN 3141:2004 on samples tested both dry and after soaking in water at temperature of $20{ }^{\circ} \mathrm{C}$ for $24 \mathrm{~h}$ (according to clause 5.1.1 of EN 314-1). In order to determine mechanical properties of plywood, such as modulus of elasticity (MOE) and modulus of rigidity (MOR), relevant tests were carried out according to EN 310 (1993), parallel and perpendicular to the grain. Statistical analysis of mechanical properties and bonding quality was carried out on 15 samples in each test. Average humidity content of plywood samples intended for tests was $5 \%$. Both in case of veneers and manufactured panels, the moisture content was calculated according to EN 322:1999. The amount of released formaldehyde was investigated using the flask method in accordance with EN 717-3:1996. Obtained results were subjected to statistical analysis using Statistica software. The Tukey test was carried out with the significance level $\alpha=0.05$.

\section{RESULTS AND DISCUSSION} 3. REZULTATI I RASPRAVA

The IR spectra of both cured unmodified and modified UF resin are presented in Figure 1. The spectra of the UF resin without cellulosic particles and with MFC and NFC were almost the same. The spectra of adhesive mixtures revealed characteristic functional groups of typical cured UF resins such as a broad $\mathrm{NH}$, $\mathrm{OH}$ stretching at around $3100-3500 \mathrm{~cm}^{-1}$, amide I, II and $\mathrm{C}=\mathrm{O}$ at $1650-1550 \mathrm{~cm}^{-1}$ and $\mathrm{CH}_{2} \mathrm{OH}, \mathrm{CH}_{3}$ and $\mathrm{CN}$ at $1400-1360 \mathrm{~cm}^{-1}$. IR-spectra confirmed that the addition of cellulose particles did not considerably affect the chemical structure of the cured UF resin. In future, it would be interesting to investigate the chemical interaction between modifier and adhesive using other spectroscopic methods.

While many research concerning the polymers modification with a natural fibre can be found, there is a very limited access to information about rheological behaviour and curing properties of the nanocellulosereinforced adhesives intended for the production of wood-based materials (Richter et al., 2009; LópezSuevos et al., 2010). Properties of urea-formaldehyde resin with the addition of different amounts of MFC and NCC are shown in Table 2.

Table 2 Characteristics of adhesive mixture Tablica 2. Svojstva smjesa adheziva

\begin{tabular}{|c|c|c|c|}
\hline $\begin{array}{c}\text { Variant } \\
\text { Varijanta }\end{array}$ & $\begin{array}{c}\text { Gel time, s } \\
\text { Vrijeme geliranja, s }\end{array}$ & $\mathbf{p H}$ & $\begin{array}{c}\text { Solid content, \% } \\
\text { Čvrsta } \text { tvar, \% }\end{array}$ \\
\hline 0 & 69 & 8.2 & 67.2 \\
\hline M5 & 69 & 8.4 & 61.5 \\
\hline M10 & 75 & 8.4 & 45.6 \\
\hline M20 & 93 & 8.5 & 42.2 \\
\hline N5 & 71 & 8.3 & 62.8 \\
\hline N10 & 94 & 8.2 & 56.9 \\
\hline N20 & 119 & 8.4 & 51.5 \\
\hline
\end{tabular}




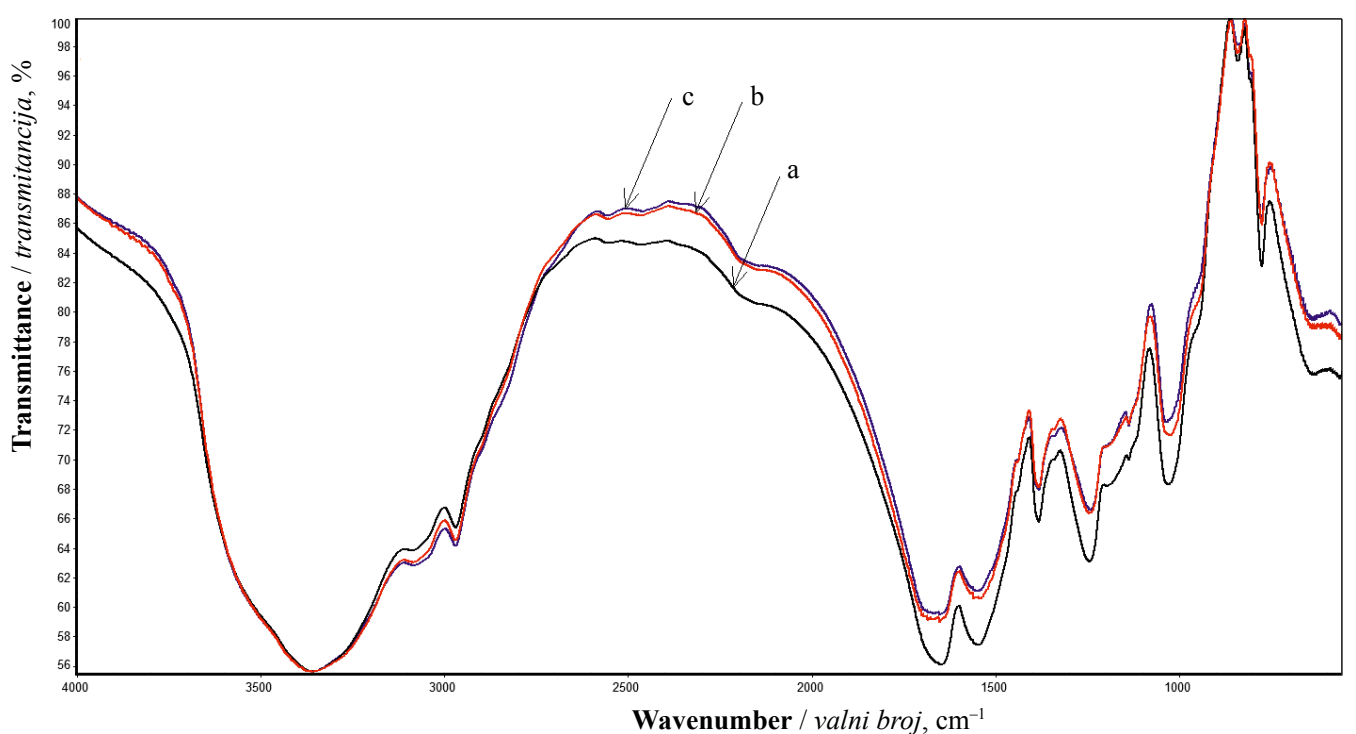

Figure 1 IR spectra of: (a) - unmodified UF resin; (b) - NCC+UF resin labelled as N10; (c) - MFC+UF resin labelled as M10

Slika 1. IC spektar: a) - nemodificirana UF smola; b) - NCC+UF smola označena kao N10; c) - MFC+UF smola označena kao M10

On the basis of data presented in Table 2, it was found that as the amount of MFC and NCC suspension is increased, the gel time of adhesive mixture is extended. This may be caused by lowering solid content of the resin due to extra water added with the aqueous cellulosic suspension, which was expected based on previous studies (Veigel et al., 2012). In a recent study, Mahrdt et al. (2016) revealed that the addition of cellulosic particles had a significant effect on urea-formaldehyde adhesives cure kinetics. Moreover, due to the hydrophilic properties of cellulose, it was noted that cellulose micro- and nanoparticles can prevent water from evaporating during the pressing, which can be technologically disadvantageous and can affect the productivity. $\mathrm{pH}$ level of the adhesive mixtures remained stable regardless of the type and amount of filler addition. The results of viscosity and its changes are presented in Figure 2.

As expected based on the hydrophilic properties of fillers and earlier studies (Veigel et al., 2012; Mahrdt et al., 2016), viscosity has significantly changed during the test time. However, a different amount of rye flour added to adhesive mixture seems to reduce the differ- ences between the variants and make reinforced adhesives comparable to control adhesive prepared in accordance with industrial recipe. Relatively high viscosity of MFC-UF and NCC-UF resins at the beginning of the test was caused by considerable interfibrillar interaction. Surfaces of cellulosic fibrils are covered with hydroxyl groups that can lead to the formation of temporary bonds between the adjacent fibrils (Iotti et al., 2011). Fig 2 also shows a slightly higher viscosity in the case of NCC-UF compared to MFC-UF mixture. It can be caused by the fact that particles in a nanoscale have increased chemical reactivity of their surface. which leads to the formation of agglomerates (Shahbazi et al., 2013).

Results of shear strength $\left(f_{\mathrm{v}}\right)$ of manufactured plywood are presented in Table 3. Studies revealed that modification of UF resin with cellulosic particles had a positive effect on the bonding quality in all variants, regardless of the amount and type of filler added to adhesive mixture.

The statistical analysis shows that the type of modifier had a significant effect on the bonding quality of plywood. Plywood manufactured with NCC-UF

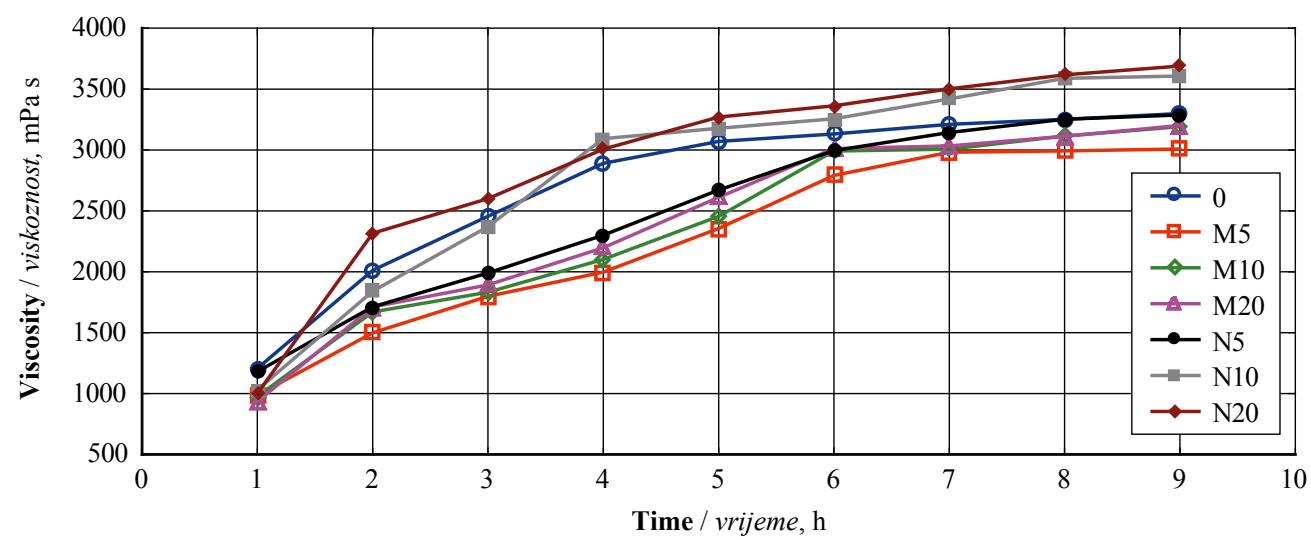

Figure 2 Changes in viscosity during 8-hour test depending on the variant of adhesive mixture Slika 2. Promjene viskoznosti ovisne o varijanti smjese adheziva uočene tijekom 8-satnog ispitivanja 
Table 3 Shear strength of plywood depending on the variant of used adhesive mixture

Tablica 3. Čvrstoća na smicanje furnirske ploče u ovisnosti o varijanti smjese adheziva

\begin{tabular}{|c|c|c|}
\hline \multirow{2}{*}{$\begin{array}{c}\text { Variant } \\
\text { Varijanta }\end{array}$} & \multicolumn{2}{|c|}{$\boldsymbol{f}_{\mathbf{v}}, \mathbf{N} / \mathbf{m m}^{\mathbf{2}}$} \\
\cline { 2 - 3 } & $\begin{array}{c}\text { Tested dry } \\
\text { Ispitivano nasuho }\end{array}$ & $\begin{array}{c}\text { After 24h of soaking } \\
\text { Nakon 24-satnog potapanja }\end{array}$ \\
\hline 0 & $1.818(0.264) \mathrm{a}$ & $1.558(0.395) \mathrm{a}$ \\
\hline M5 & $1.978(0.267) \mathrm{b}$ & $1.680(0.285) \mathrm{ab}$ \\
\hline M10 & $2.313(0.280) \mathrm{c}$ & $2.015(0.262) \mathrm{cd}$ \\
\hline M20 & $2.171(0.291) \mathrm{cb}$ & $1.824(0.205) \mathrm{abc}$ \\
\hline $\mathrm{N} 5$ & $2.083(0.301) \mathrm{cb}$ & $1.753(0.309) \mathrm{abc}$ \\
\hline $\mathrm{N} 10$ & $2.612(0.287) \mathrm{d}$ & $2.219(0.389) \mathrm{d}$ \\
\hline $\mathrm{N} 20$ & $2.291(0.212) \mathrm{c}$ & $1.890(2.248) \mathrm{bc}$ \\
\hline
\end{tabular}

(...) - Standard deviation / standardna devijacija; a,b,c,d - homogeneous groups (Tukey test, $\alpha=0.05$ ) / homogenost skupina

resin achieved considerable better shear strength results than control samples and samples with MFC-UF adhesive. However, both in case of plywood glued with resin modified by microcellulose and nanocellulose, the amount of modifier was also important similarly as in the research of Richter et al., (2009). Addition of NCC and MFC in the amount of $5 \% / 100 \mathrm{~g}$ of solid resin led to a slight increase of shear strength. Regardless of the type of filler, the best results were obtained for the amount of $10 \% / 100 \mathrm{~g}$ of solid resin. Introducing $10 \%$ of MFC caused the increase in bonding quality by about $27 \%$ and $29 \%$, respectively, in case of samples tested dry and after soaking. The most significant change was noted in case of $10 \%$ addition of NCC and it was approx. $44 \%$ in comparison to plywood glued with unmodified resin. As expected based on the recent studies of Veigel et al. (2012), further addition of the filler led to a decrease of joint properties. Most importantly, regardless of the type and amount of added cellulosic particles, the results of all plywood shear strength exceeded a value $1 \mathrm{~N} / \mathrm{mm}^{2}$ required by the standard EN 314-2:1993.

Table 4 reveals an improvement of mechanical properties, i.e. modulus of elasticity and modulus of rigidity, caused by addition of both MFC and NCC to UF resin. Plywood samples were tested parallel and perpendicular to the grain of face layers.

Similarly as in the case of statistical analysis of bonding quality results, the type of filler had a significant effect on $M O R$ and $M O E$ values. Only in the case of modulus of elasticity assessed parallel to the grain, based on the Tukey's test performed, it was not possible to determine separate homogeneous groups with the significance level $\alpha=0.05$ as in the case of recent studies of Dukarska and Czarnecki (2016). The addition of NCC had more considerable effect on the MOR and $M O E$ of plywood in comparison with the panels glued with MFC-UF resin and unmodified resin. On the basis of the data presented in Table 4, it can be concluded that the best results were obtained by the addition of $10 \% \mathrm{NCC} / 100 \mathrm{~g}$ of solid resin. Values of modulus of rigidity were increased by about $34 \%$ and $66 \%$, respectively, parallel and perpendicular to the grain of face veneer layer. Modulus of elasticity was mostly correlated with $M O R$ and has shown similar results. In case of considered mechanical properties, the trend was very similar as in case of bonding quality of plywood. $5 \%$ addition of MFC and NCC to $100 \mathrm{~g}$ of solid resin led to a slight increase of modulus of rigidity and modulus of elasticity. However, further filler addition at the level of $20 \%$ caused a decrease of the above mentioned properties. Thus, as expected based on recent studies, the amount of nano-modifier had a significant effect on the mechanical performance of plywood.

The formaldehyde emission values from the manufactured plywood panels are presented in Table 5 . To determine the amount of formaldehyde release, the flask method was used.

Applying small amounts of MFC and NCC (5\% by weight of solid resin) led to a slight decrease in formaldehyde emission, which is similar to recent studies on the addition of other nanoparticles to adhesives, e.g. nano-SiO (Dukarska and Czarnecki, 2016). However, further addition of micro- and nanocellulose to UF resin resulted in an increase of formaldehyde emission compared to control samples. On the basis of the presented data, it cannot be clearly concluded that

Table 4 Modulus of Rigidity $(M O R)$ and Modulus of Elasticity $(M O E)$ depending on the variant of used adhesive mixture Tablica 4. Modul krutosti $(M O R)$ i modul elastičnosti $(M O E)$ u ovisnosti o varijanti upotrijebljene smjese adheziva

\begin{tabular}{|c|c|c|c|c|}
\hline \multirow{2}{*}{$\begin{array}{c}\text { Variant } \\
\text { Varijanta }\end{array}$} & \multicolumn{2}{|c|}{ MOR, N/mm } & \multicolumn{2}{c|}{ MOE, N/mm } \\
\cline { 2 - 4 } & $\|$ & $\perp$ & $\|$ & $\perp$ \\
\hline 0 & $135.08(15.3) \mathrm{a}$ & $23.01(2.1) \mathrm{a}$ & $13342(1547) \mathrm{a}$ & $1549.7(208.1) \mathrm{a}$ \\
\hline M5 & $143.74(24.5) \mathrm{ab}$ & $25.10(3.4) \mathrm{ab}$ & $13753(1447) \mathrm{a}$ & $1630.4(263.2) \mathrm{ab}$ \\
\hline M10 & $163.81(9.9) \mathrm{cd}$ & $32.18(1.7) \mathrm{c}$ & $14149(1907) \mathrm{a}$ & $1781.8(177.5) \mathrm{abc}$ \\
\hline M20 & $150.09(8.6) \mathrm{abc}$ & $27.39(2.2) \mathrm{b}$ & $13813(1462) \mathrm{a}$ & $1726.9(192.7) \mathrm{abc}$ \\
\hline N5 & $150.61(14.8) \mathrm{abc}$ & $25.31(2.9) \mathrm{ab}$ & $13779(1805) \mathrm{a}$ & $1746.8(200.2) \mathrm{abc}$ \\
\hline N10 & $180.49(13.1) \mathrm{d}$ & $38.14(3.3) \mathrm{d}$ & $15059(1401) \mathrm{a}$ & $1955.8(164.5) \mathrm{c}$ \\
\hline N20 & $160.64(10.2) \mathrm{bc}$ & $30.98(2.1) \mathrm{c}$ & $14198(1410) \mathrm{a}$ & $1881.1(239.4) \mathrm{bc}$ \\
\hline
\end{tabular}

(...) - Standard deviation / standardna devijacija; a,b,c,d - homogeneous groups (Tukey test, $\alpha=0.05$ ) / homogenost skupina 
Table 5 Formaldehyde emission from manufactured plywood depending on the variant of used adhesive mixture Tablica 5. Emisija formaldehida iz proizvedene ploče u ovisnosti o varijanti upotrijebljene smjese adheziva

\begin{tabular}{|c|c|}
\hline $\begin{array}{c}\text { Variant } \\
\text { Varijanta }\end{array}$ & $\begin{array}{c}\text { Formaldehyde content, } \mathbf{m g} \mathbf{C H} \mathbf{O} / \mathbf{k g} \\
\text { Sadržaj formaldehida, } \mathrm{mg} \mathrm{CH}_{2} \mathrm{O} / \mathrm{kg}\end{array}$ \\
\hline 0 & 2.253 \\
\hline $\mathrm{M} 5$ & 2.045 \\
\hline $\mathrm{M} 10$ & 2.509 \\
\hline $\mathrm{M} 20$ & 2.653 \\
\hline $\mathrm{N} 5$ & 2.116 \\
\hline $\mathrm{N} 10$ & 2.255 \\
\hline $\mathrm{N} 20$ & 2.258 \\
\hline
\end{tabular}

the addition of MFC or NCC significantly decreased the amount of formaldehyde emission, which is similar to recent studies of Ayrilmis et al. (2016). The possible reason of decrease in formaldehyde emission could be the fact that nanoparticles can absorb free formaldehyde from adhesives (Liu and Zhu, 2014). Moreover, it was previously reported that barrier properties of nanoparticles can reduce the amount of emitted formaldehyde due to the shielding effect. The slight increase of formaldehyde emission in some variants may be caused by aggregation of the particles in the adhesives mixture filled with cellulose (Ayrilmis et al., 2016). As a future work, it would be interesting to modify the surface of cellulosic fibrils, e.g. with 3-aminpropyltriethoxysilane (APTES) or 3-methacryloxypropyltrimetoxysilane (MPS). The emission of $\mathrm{CH}_{2} \mathrm{O}$ from plywood glued with UF resin modified with NCC was reduced by adsorption and chemisorptions, which seems to be caused by modification of nanoparticles with APTES (Zhang et al., 2011).

\section{CONCLUSIONS}

\section{ZAKLJUČAK}

On the basis of the IR-spectra, it can be concluded that the addition of cellulose particles did not considerably affect the chemical structure of the cured UF resin. However, the presented results show that the addition of both MFC and NCC to UF resin made it more viscous, which can delay its gel time, and this limits the possible addition level of cellulosic particles. The addition of cellulose improved the bonding quality and mechanical properties of plywood in all variants of modification but definitely the best results were obtained for the addition of $10 \%$ NCC per $100 \mathrm{~g}$ of solid resin. The use of $5 \% \mathrm{NCC}$ and MFC/100 $\mathrm{g}$ of solid resin led to a slight decrease in formaldehyde emission but further increase of the amount of modifier did not reduce the amount of formaldehyde emitted from the plywood.

\section{REFERENCES}

\section{LITERATURA}

1. Ahmad, Z.; Ansell, M. P.; Smedley, D., 2010: Epoxy adhesives modified with nano- and micro-particles for in situ timber bonding: effect of microstructure on bond integrity. Int J Mech Mater Eng, 5 (1): 59-67. https://doi.org/10.1007/s10570-011-9576-1.
2. Ates, E.; Uyanik, N.; Kizilcan, N., 2013: Preparation of urea formaldehyde resin/layered silicate nanocomposites. Pigm. Resin Technol., 42 (5): 283-287. https://doi.org/10.1108/PRT-07-2012-0043.

3. Ayrilmis, N.; Lee, Y.-K.; Kwon, J. H.; Han, T.-H.; Kim, H.-J., 2016: Formaldehyde emission and VOCs from LVLs produced with three grades of urea-formaldehyde resin modified with nanocellulose. Build. Environ., 97: 82-87. https://doi.org/10.1016/j.buildenv.2015.12.009.

4. Bardak, T.; Naci, A.; Tankut, N.; Aydemir, D.; Sozen, E., 2017: The bending and tension strength of furniture joints bonded with polyvinyl acetate nanocomposites. Madera Cienc. Tecnol., 19 (1): 51-62.

http://dx.doi.org/10.4067/S0718-221X2017005000005.

5. Bekhta, P.; Bryn, O.; Sedliačik, J.; Novák, I., 2016: Effect of different fire retardants on birch plywood properties. Acta Facultatis Xylologiae Zvolen, 58 (1): 59-66. https://doi.org/10.17423/afx.2016.58.1.07.

6. Dukarska, D., 2013: The effect of an addition of nano$\mathrm{SiO}_{2}$ to urea resin on the properties of board manufactured from rape straw. Ann. WULS-SGGW, For. and Wood Technol., 82: 242-245.

7. Dukarska, D.; Czarnecki, R., 2016: Fumed silica as a filler for MUPF resin in the process of manufacturing water-resistant plywood. Eur. J. Wood Prod. 74 (1): 5-14. https://doi.org/10.1007/s00107-015-0955-4.

8. Dunky, M.; Niemz, P., 2002: Holzwerkstoffe und Leime - Technologie und Einflußfaktoren. Springer, Berlin.

9. Dziurka, D.; Mirski, R., 2010: UF-pMDI hybrid resin for water-proof particleboards manufactured at a shortened pressing time. Drvna industrija, 61 (4): 245-249.

10. Dziurka, D.; Turbańska, D.; Mirski, R., 2014: Ethyl acetoacetate as a formaldehyde scavenger in UF resins used to bond beech veneer. Ann. WULS-SGGW, For. and Wood Technol. 85: 53-56.

11. Gao, Q.; Liu, C.; Luo, J.; Li, X.; Chen, L.; Wang, W.; Li, J., 2018: Effects of resin open time and melamine addition on cold pre-pressing performance of urea-formaldehyde resin. Eur. J. Wood Prod., 76: 1253-1261. https://doi.org/10.1007/s00107-018-1307-y.

12. Hubbe, M. A.; Rojas, O. J.; Lucia, L. A.; Sain, M., 2008: Cellulosic nanocomposites: a review. BioResources, 3 (3): 929-980.

13. Ioelovich, M., 2008: Cellulose as a nanostructured polymer: a short review. BioResources, 3 (4): 1403-1418.

14. Iotti, M.; Gregersen, Ø. W.; Moe, S.; Lenes, M., 2011: Rheological studies on microfibrillar cellulose water dispersions. J Polym Environ, 19 (1): 137-145. https://doi.org/10.1007/s10924-010-0248-2.

15. Klemm, D.; Heublein, B.; Fink, H. P.; Bohn, A., 2005: Cellulose: Fascinating biopolymer and sustainable raw material. Angewadnte Chemie International Edition, 44 (22): 3358-3393.

https://doi.org/10.1002/anie.200460587. 
16. Łęcka, J.; Dukarska, D.; Matelewski, H., 2013: Effect of addition of titanium dioxide and talc on properties of phenolic resin and water-resistant plywood. Ann. WULSSGGW, For. and Wood Technol., 83: 191-195.

17. Lei, H.; Du, G.; Pizzi, A.; Celzard, A., 2008: Influence of nanoclay on urea-formaldehyde resins for wood adhesives and its model. J Appl Polym Sci, 109 (4): 24422451. https://doi.org/10.1002/app.28359.

18. Leonovich, A. A.; Kovrizhnykh, L. P.; Korneev, V. I.; Bodoyavlenskya, G. A.; Madvedeva, I. N., 2002: Silicon dioxide sol as a component of urea-formaldehyde adhesive. Rus J Appl Chem, 75 (8): 1336-1338. https://doi.org/10.1023/A:1020981532085.

19. Lin, Q.; Yang, G.; Liu, J.; Rao, J., 2006: Property of nano- $\mathrm{SiO}_{2} /$ urea formaldehyde resin. Front For China, 1: 230-237. https://doi.org/10.1007/s11461-006-0024-6.

20. Liu, Y.; Zhu, X., 2014: Measurement of formaldehyde and VOCs emissions from wood-based panels with nanomaterial-added melamine-impregnated paper. Constr. Build. Mater., 66: 132-137. https://doi.org/10.1016/j.conbuildmat.2014.05.088.

21. López-Suevos, F.; Eyholzer, C.; Bordeanu, N.; Richter, K., 2010: DMA analysis and wood bonding of PVAc latex reinforced with cellulose nanofibrils. Cellulose, 17 (2): $387-$ 398. https://doi.org/10.1007/s10570-010-9396-8.

22. Mahrdt, E.; Pinkl, S.; Schmidberger, C.; Van Herwijnen, H. W. G.; Veigel, S.; Gindl-Altmutter, W., 2016: Effect of addition of microfibrillated cellulose to urea-formaldehyde on selected adhesive characteristics and distribution in particle board. Cellulose, 23 (1): 571-580. https://doi.org/10.1007/s10570-015-0818-5.

23. May, M.; Wang, H. M.; Akid, R., 2010: Effects of the addition of inorganic nanoparticles on the adhesive strength on the adhesive strength of hybrid sol-gel epoxy system. Int J Adhes Adhes, 30 (6): 505-512. https://doi.org/10.1016/j.ijadhadh.2010.05.002

24. Munoz, F.; Moya, R., 2018: Effect of nanoclay-treated UF resin on the physical and mechanical properties of plywood manufactured with wood from tropical fast growth plantations. Maderas Cienc Technol, 20 (1): 11-24. http://dx.doi.org/10.4067/S0718-221X2018005001202.

25. Pawlak, D.; Boruszewski, P., 2018: Influence of addition of microfibrillated cellulose (MFC) on selected properties of low-density particleboard. Ann. WULS-SGGW, For. and Wood Technol., 102: 139-148.

26. Richter, K.; Bordenau, N.; Lópe-Suevos, F.; Zimermann, T., 2009: Performance of cellulose nanofibrils in wood adhesives. Proceeding of the Swiss Bonding, Rapperswill, Swizerland, 239-246.

27. Roumeli, E.; Papadopoulou, E.; Pavludou, E.; Vourlias, G.; Bikiaris, D.; Paraskevopoulos, K. M.; Chrissafis, K., 2012: Synthesis, characterization and thermal analysis of urea-formadehyde/nanoSiO ${ }_{2}$ resin. Thermochim Acta, 527: 33-39. https://doi.org/10.1016/j.tca.2011.10.007.

28. Shahbazi, M.-A.; Hamidi, M.; Mäkilä, E. M.; Zhang, H.; Almeida, P. V.; Kaasalainen, M.; Salonen, J. J.; Hirvonen,
J. T.; Santos, H., 2013: The Mechanisms of Surface Chemistry Effects of Mesoporous Silicon Nanoparticles on Immunotoxicity and Biocompatibility. Biomaterials, 34 (31): 7776-7789.

https://doi.org/10.1016/j.biomaterials.2013.06.052.

29. Veigel, S.; Muller, U.; Keckes, J.; Obsersriebnig, M.; Gindl-Almutter, W., 2011: Cellulose nanofibrils as filler for adhesives: effect on specific fracture energy of solid wood-adhesive bond. Cellulose, 18: 1227-1237. https://doi.org/10.1007/s10570-011-9576-1.

30. Veigel, S.; Rathke, J.; Weigl, M.; Gindl-Almutter, W., 2012: Particle board and oriented strand board prepared with nanocellulose-reinforced adhesive. Journal of Nanomaterials. https://doi.org/10.1155/2012/158503.

31. Zahedsheijani, R.; Faezipour, M.; Tarmian, A.; Layeghi, M.; Yousefi, H., 2012: The effect of $\mathrm{Na}^{+}$montmorillonite (NaMMT) nanoclay on thermal properties of medium density fiberboard (MDF). Eur. J. Wood Prod., 70 (5): 565-571. https://doi.org/10.1007/s00107-011-0583-6.

32. Zhang, H.; Zhang, J.; Song, S.; Wu, G.; Pu, J., 2011: Modified nanocrystalline cellulose from two kinds of modifiers used for improving formaldehyde emission and bonding strength of urea-formaldehyde resin adhesive. BioResources, 6 (4): 4430-4438.

33. ${ }^{* * *} \mathrm{EN} 1245$, 2011: Adhesives - Determination of $\mathrm{pH}$.

34. ***EN 310, 1993: Wood-Based Panels. Determination of Modulus of Elasticity in Bending and of Bending Strength.

35. ***EN 314-1, 2004: Plywood. Bonding quality. Test methods.

36. ***EN 314-2, 1993: Plywood. Bonding quality. Requirements.

37. ${ }^{* * *}$ EN 322, 1999: Wood-based panels - Determination of moisture content.

38. ***EN 717-3, 1996: Wood-Based Panels - Determination of Formaldehyde Release - Part 3: Formaldehyde Release by the Flask Method.

39. ${ }^{* * *} \mathrm{EN} 827,2005$ : Adhesives - Determination of conventional solid content and constant mass solids content.

40. ***PN-C-89352-3, 1996: Wood adhesives. Test methods - Determination of gelation time (in Polish).

\section{Corresponding address:}

\section{MSc JAKUB KAWALERCZYK}

Department of Wood Based Materials

Faculty of Wood Technology

Poznań University of Life Sciences

Wojska Polskiego Street 38/42

60-637 Poznań, POLAND

e-mail: jakub.kawalerczyk@up.poznan.pl 